総

説

スパッタ法・めつき法によるフェライト薄膜の堆積技術と構造·物性の比較

北本 仁孝, 中川 茂樹, 阿部 正紀, 直江 正彦

東京工業大学工学部電子物理工学科, $₹ 152-8552$ 目黒区大岡山 2-12-1

\title{
Microstructure and Magnetic Properties of Ferrite Thin Films Prepared by Sputtering and Plating
}

\author{
Yoshitaka Kitamoto, Shigeki Nakagawa, Masanori Abe and Masahiko Naoe \\ Department of Physical Electronics, Tokyo Institute of Technology, 2-12-1 O-okayama, Meguro-ku, Tokyo 152-8552.
}

Received October 22, 1999

\section{SYNOPSIS}

The present paper describes synthesis techniques of ferrite thin films by the facing-targets sputtering and the ferrite-plating methods. The difference in microstructure, crystallinity and magnetic properties of the ferrite films deposited by the two deposition methods is caused by the difference in energy which atoms and ions have in order to migrate on and around substrates. Co-M ferrite films ( $M=Z n, N i)$ deposited by the two methods for magnetic recording media were investigated. Since the sputtered atoms have higher migration energy than the plating ions, the sputterdeposited $\mathrm{Co}-\mathrm{Zn}$ ferrite films exhibited closely packed finer microstructure, better crystallinity, and higher mechanical strength. Co-Ni ferrite-plated films had excellent perpendicular magnetic anisotropy though the microstructure must be improved to apply to the magnetic recording media. The ferrite plating has the advantages in coating micrometersize particles used as magnetically separable carriers such as for medical applications because it is a wet process.

KEY WORDS

ferrite thin film, facing targets sputtering, ferrite plating, magnetic recording medium, ferrite-coated particle

\section{1 緒言}

フェライトは金属や合金の磁性体と異なり,化学的安定性, 機械的強度に優れるばかりでなく，電気的に絶縁体であるた めに高周波テバイスへの応用にも適している．また，鉄を主 成分としているため，他の強磁性体と比較して安価な磁気製 品が数多く市場に出回っているが，これらのほとんどはバル クであり，フェライトを薄膜として応用したデハイスという 観点から見ると，その優れた特性にもかかわらず応用例は極 めて少ない，これは，結晶性，磁気特性に優れた薄膜の形成 が困難である上に，その作製には高温が必要とされるといっ た不利のためであると考えられる. 本稿では，このような作 製上の久点を克服するフェライト薄膜作製法として，対向 ターゲット式スパッタ法とフェライトめっき法とをとりあげ， それそれの手法の特長を述べるとともに，磁気記録媒体への 応用を目指したC フェライト膜について両者の方法で作製し た膜の構造, 磁気特性について述べる.さらに，めつき法で は作製困難なマグネトプラムバイト型 $\mathrm{Ba}(\mathrm{BaM})$ フェライト薄 膜形成の対向ターグット式スパッタ法による低温化と, めつ
き法の特長を生かしたポリマー超微粒子へのフェライト・ コートについても述べる。

2 対向ターゲット式スパッタ法

スパッ夕法による薄膜形成において常に重要とされる点は, プラスマや高エネルギー粒子の衝盤による膜の損傷を防ぐこ とである．基板がターゲットと向かい合うように配置された 2極スパッタ法だけでなく，磁界によりプラズマの広がりを抑 えているマグネトロンスパッタ法においても $\gamma$ 電子や高速粒 子の膜への衝突によるダメージは避けることが困難である. 特に，磁性体ターゲットを用いたマグネトロンスパッタ法の 場合にはターゲット表面への漏れ磁束が弱くなるために，プ ラスマの閉じ込めか不十分になるからである.

一方, Fig.1に示す対向夕ーゲット式スパッ夕法"では，2枚 のターゲットを対向させ, ターゲットの背面の周辺部にのみ 磁石を取付け，ターゲット面に垂直な磁界を印加する．その ため, 磁性体ターゲットであっても $\gamma$ 電子を両ターグット間に 閉じ込めることができ,動作ガスのイオン化を促進するため， 
高密度のプラズマがターゲット間に拘束され, $10^{-4} \sim 10^{-5}$ Torr の動作ガス圧力でも安定な放電が可能であると同時に，低印 加電圧で高効率のスパッタが可能なので, 高堆積速度を実現 することができる. また，基板はターゲットの周囲に配置さ れているため, $\gamma$ 電子やガスイオンなどの高エネルギー粒子の 基板・膜面への衝擊を抑制することができる.

その結果として, 結晶性の高い薄膜を得ることができると ともに，組成ずれが起きないためフェライト膜作製において 重要な組成制御が容易に行えるようになった。フェライトで は酸素イオンの面心立方格子の隙間にFeなどの金属イオンが 入るため, その配列状態や組成は膜の磁気特性に強く影響を 与える.そのため, プラスマによる膜面衝擊のない対向ター ゲット式スバッ夕法では, 結晶性が高く, 組成ずれのない, 優 れた磁気特性を有するフェライト薄膜の作製が可能である。

微細構造の面でも動作ガス圧力を $10^{-4}$ Torr 台以下にするこ とが可能なので, スパッタ原子の平均自由工程がターゲット から基板までの距離よりも長くなり，ガスやイオンと衝突す ることなくスパッタされたときのエネルギーをそのまま維持 して基板に到達する. それにより，基板上での原子のマイク レーションが十分に行えるために, 破断面に柱状構造などが 観察されない緛密で平滑な膜が形成される.これがスパッ夕 法の, 特に対向ターゲット式スバッタ法の特長であり, 膜作 製にかかわる原子に高いエネルギーを供給することができる というスパッタ法の特長を十分に引き出した手法であるとい える. そのため, 磁気ティスク・ヘッドなどのナノ構造を要 求するテバイスへの応用が期待される.

\section{3 フェライトめっき法}

フェライトめっきでは, 種々の組成のスピネル型酸化物薄 膜を $100^{\circ} \mathrm{C}$ 以下の水溶液中で直接, 結晶質膜として得ること ができる.そのため, プラスチック等の有機物を含め, 耐熱 性のない物質をも基板として用いることができるので，結晶 化のため数 $100^{\circ} \mathrm{C}$ 以上の高温での基板加熱を必要とするドラ イプロセス (LPE, CVD，スバッタ，熱分解，プラスマ溶射等) では作製できない新しいデバイスを作製できる方法として注 目されている. また, ウエットプロセスであるため, チュー

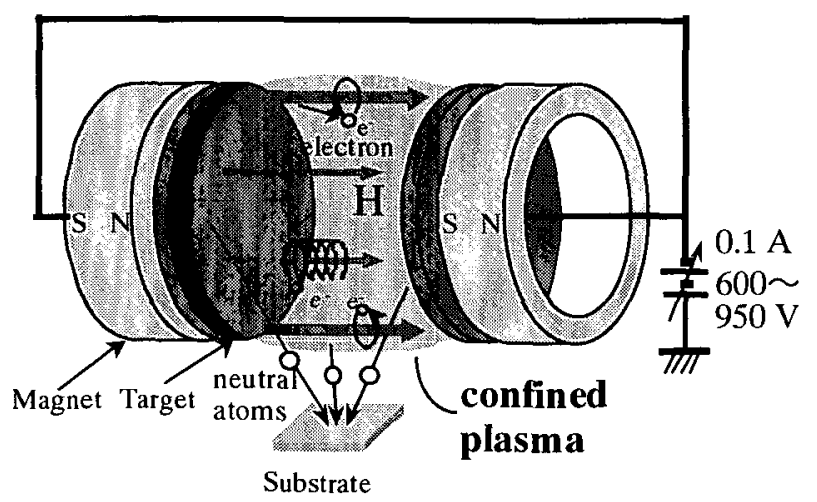

Fig.1 Schematic diagram of facing targets sputtering system.
ブの内壁や複雑な凹凸を持った物体，超微粒子の表面を均一 にフェライト膜でコーティングできるだけでなく，水溶液中 で作製されるため水や有機物との親和性が良く, 電気化学的, 生物・医学的応用に対して有利であるという特長を持つ.さ らに，薄膜作製のために高真空・高温を必要としないので製 造設備への投資を軽隇することができるだけでなく，製造段 階で消費・排出されるエネルギーが少ないため環境に優しい ソフト・プロセスという特徵を有する。

フェライト生成反応は次のとおりである2)．Fig.2に示すよ うに，金属イオンの吸着席となる $\mathrm{OH}$ 基， $\mathrm{COOH}$ 基などが表 面に出ている基板を，2価鉄イオン $\mathrm{Fe}^{2+}$ 及びその他の金属イオ ン $\mathrm{M}^{\mathrm{n}+}$ を含む反応液 $\left(\mathrm{pH}=5 \sim 11\right.$, 温度 $\mathrm{T}=60 \sim 100^{\circ} \mathrm{C}$ ) 中に浸す と、これらのイオンか吸着される. 次に, 亜硝酸イオン $\left(\mathrm{NO}^{2}\right)$, 空気 $\left(\mathrm{O}_{2}\right)$, 陽極電流 $\left(\mathrm{e}^{\mathrm{e}}\right)$ などの酸化剂によって $\mathrm{Fe}^{2+} \rightarrow \mathrm{Fe}^{3+}$ の酸 化反応を行うと，スビネル $\left((\mathrm{Fe}, \mathrm{M})_{3} \mathrm{O}_{4}\right)$ 生成反応が起こる.こ の「吸着 $\rightarrow$ 酸化 $\rightarrow$ ズネル生成」というプロセスか繰り返さ れ，スピネル膜が成長していく.基板としては，表面に $\mathrm{OH}$ 基 を有し反応液に対して安定であれば良く, $\mathrm{SiO}_{2}, \mathrm{Al}_{2} \mathrm{O}_{3}$, ガラス などの酸化物およびセルロースやプラスチックなどの有機物 を用いることができる．反応液には $\mathrm{Fe}^{2+}$ およびその他の金属 イオンの坫酸塩, 硝酸塩, 硫酸塩などの水溶液を用いる.酸 化液には，現在行っているほとんどの方法では亜硝酸ナトリ ウム $\left(\mathrm{NaNO}_{2}\right)$ を溶解させた水を用い,これに $\mathrm{pH}$ 調整剂として 酷酸アンモニウム $\left(\mathrm{CH}_{3} \mathrm{COONH}_{4}\right)$ あるいはアンモニアを加え, 酸化剂として用いている.また，この反応の特幑はフェライ 卜生成の原材料として $\mathrm{Fe}^{3+}$ を用いるのではなく， $\mathrm{Fe}^{2+}$ を用いて $\mathrm{Fe}^{3+}$ に酸化する反応をともなうことである.

膜生成にかかわるエネルギーという観点からスパッ夕法と 比較すると,フェライトめつき法は $100^{\circ} \mathrm{C}$ 以下で行われるこ とから，イオンや粒子のマイグレーションにかかわるエネル ギーは低い，そのため,めっき膜の破断面をSEMにより観察 すると, 真空蒸着膜や高い動作ガス圧力の条件下でのスパッ 夕膜のように明瞭な柱状構造が観察されている。この点がマ イクロ・ナノ磁気デバイスへの応用に障害となっている。

フェライトめつきでは種々の方法か研究されてきたが,2つ の方法を紹介する.まず, Fig.3に示す「スビンスプレー法」3 では，反応液と酸化液を回転する基板上にスプレーすること により，大面積 (例: 8インチ径) の基板上に均一に製膜でき る. また，Fig.4の「超音波励起法」》は，強力超音波を反応水

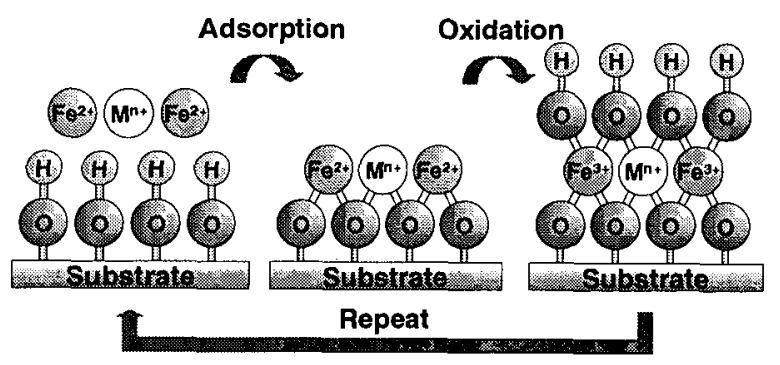

Fig.2 Principle of ferrite plating. 
溶液に直接印加することにより通常では起こらない化学反応 や物理反応を可能にする超音波化学(ソノケミストリー)とい う手法を応用したもので, これにより膜の構造的, 磁気的特 性を大幅に改善することができた。

\section{4 磁気記録媒体用Coフェライト薄膜}

高保磁力を有するCoフェライト膜は, その化学的安定性・ 機械的耐久性から, より低浮上を実現する高密度磁気ディス ク媒体としての応用が期待されている. 対向ターゲット式ス パッ夕法では化学量論組成の $\mathrm{CoFe}_{2} \mathrm{O}_{4}$ 膜のほかに $\mathrm{Co}_{0.5} \mathrm{Fe}_{25} \mathrm{O}_{4}$ 膜あるいは $\mathrm{Co}_{0.5} \mathrm{Zn}_{0.5} \mathrm{Fe}_{2} \mathrm{O}_{4}$ 膜5,6,7 が，フェライトめっき法では $\mathrm{C}_{0.5} \mathrm{Fe}_{25} \mathrm{O}_{4}$ 膜あるいはそれに $\mathrm{Ni}$ を微量添加した膜 ${ }^{8,9}$ が研究さ れている. ガラス基板上に形成したスパッ夕膜，めつき膜の 違いを表面の形態, 結晶性, 磁気特性の観点から述べる.

Fig.5 に示したのは, (a), (b) が $5 \mu \mathrm{m} \times 5 \mu \mathrm{m}$ の Co- $\mathrm{Zn}$ フェライ ト・スパッ夕膜の, (c)が $1 \mu \mathrm{m} \times 1 \mu \mathrm{m}$ の Co- $\mathrm{Ni}$ フェライトめつ き膜の表面 $\mathrm{FFM}$ 像である.スパッ夕膜とめっき膜とで添加1 オンが異なるが,これが表面状態の違いの原因になっている のではなく, スパッ夕膜とめっき膜との本質的な相違による ものと考えている. スパッ夕膜では基板温度が $400^{\circ} \mathrm{C}$ になる と結晶粒子の過度の成長のために平均表面粗さ $\mathrm{R}_{\mathrm{a}}$ は $4.0 \mathrm{~nm}$ と なるが, 基板温度が $80^{\circ} \mathrm{C}$ と低い場合には $1.0 \mathrm{~nm}$ と基板表面と

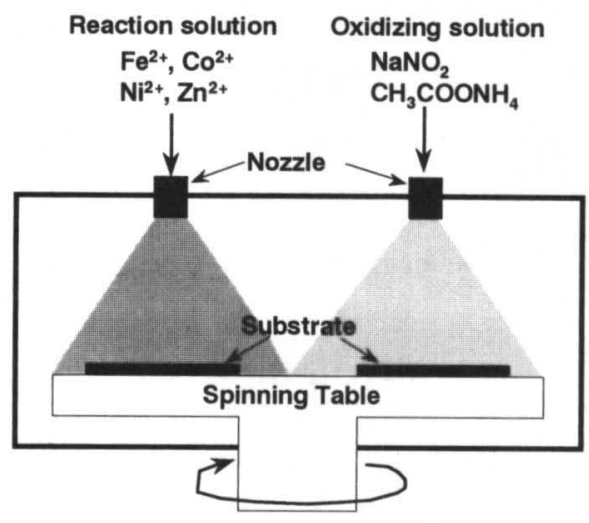

Fig.3 Schematic diagram of spin-spray ferrite-plating apparatus.

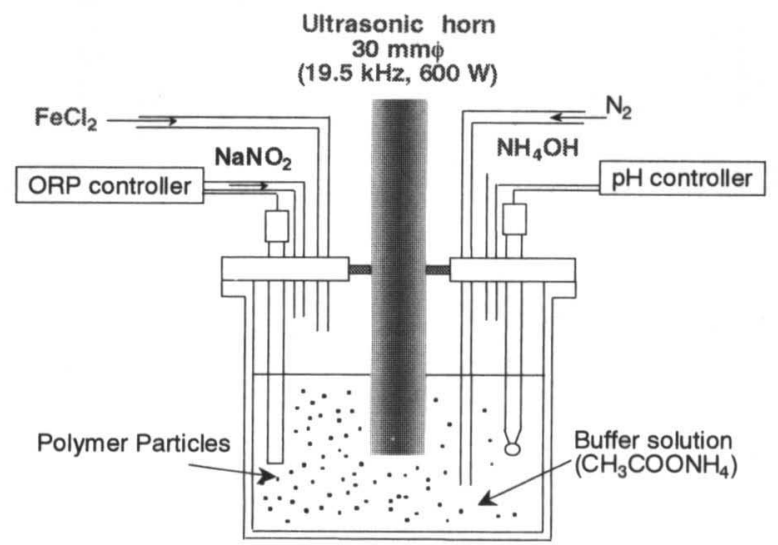

Fig.4 Schematic diagram of ultrasound-enhanced ferrite-plating apparatus.
ほほ同等の值を示した. 基板温度が高い場合の粒子の異常成 長を除けば, スパッ夕膜は本質的に(a)に示した超平滑な表面 となる.一方, (c)に示しためっき膜の場合には最適の条件で 作製した場合でも $\mathrm{R} 。$ が $3.0 \mathrm{~nm}$ と, スパッ夕膜と比較して表面 平滑性は劣る.これは膜表面で観察された粒子の寸法および そのばらつきに起因するところが大きい. (a), (b)においては 粒子までは見ることはできないが, (c)のめっき膜については 粒子寸法が 40〜 $50 \mathrm{~nm}$ であり, 中には $100 \mathrm{~nm}$ 程度のものもあ る. スパッ夕膜では同程度の膜厚の場合, 粒子寸法がめっき 膜より小さく, かつ $100 \mathrm{~nm}$ といった大きな粒子は観察されな い.このような粒子構造の相違は, 基板上での原子, イオン のマイグレーションの活性度に起因すると考えられる. すな わち, スパッ夕法ではさきに述べたように高いエネルギーを 持ったスパッ夕原子が基板に到達するため, 十分にマイグ レーションすることができ, 最適なサイトに埋め込まれて膜

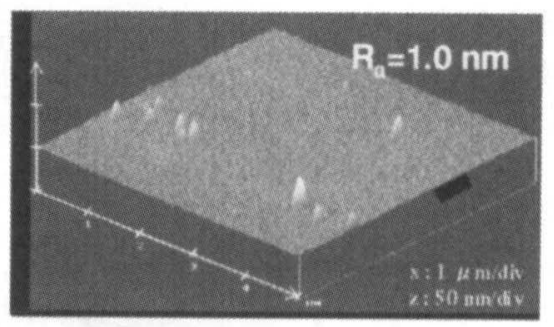

(a) Sputter-deposited Co- $\mathrm{Zn}$ ferrite film Substrate temperature: $80^{\circ} \mathrm{C}$

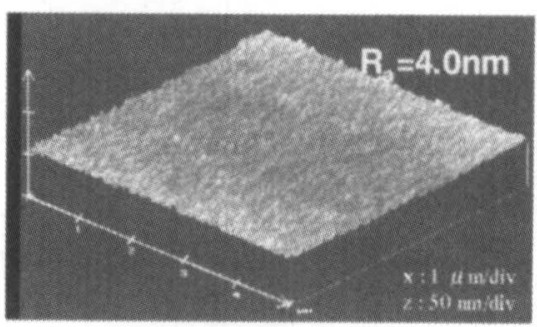

(b) Sputter-deposited Co-Zn ferrite film Substrate temperature: $400^{\circ} \mathrm{C}$

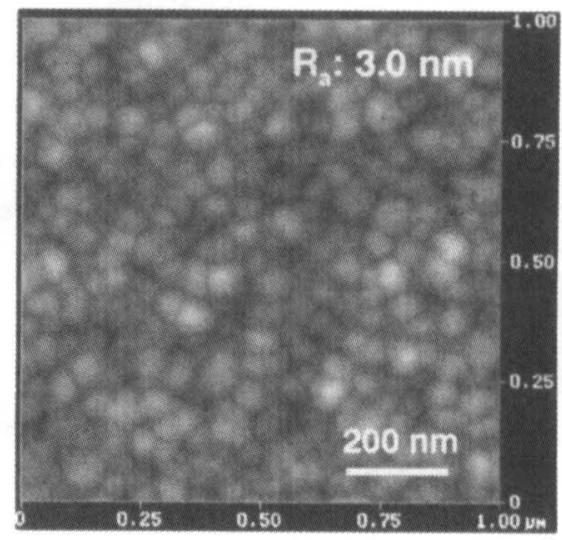

(c) Ferrite-plated Co-Ni ferrite film Substrate temperature: $90^{\circ} \mathrm{C}$

Fig.5 AFM images of (a), (b) sputter-deposited Co-Zn ferrite films and (c) ferrite-plated Co-Ni ferrite film. 
を構成していくことができる.このため, 各粒子は均一に成 長していくことができる.一方，めっき法ではそのエネル ギーが低いために基板付近でのイオンの動きが少なく，特定 の粒子が大きく成長し始めるとその他の部分では影になる陰 影効果により，その成長を㧕制することができない。

X線回折によって評価した結晶性に関しては, Co-Znフェラ イト・スパッ夕膜の場合, 基板温度が 400 から $80^{\circ} \mathrm{C}$ に下がる につれて，優先配向面が(311) から(111)に変化したように特 定の結晶面が配向する傾向にあるのに対し, $\mathrm{Co}-\mathrm{Ni}$ フェライト めっき膜では(311),(111),(110)面からの回折ピークが見られ， 特定の結晶面が配向しているわけではなかった. スパッ夕法 では十分なマイクレーションにより原子か最適なサイトに埋 め込まれていくために，比較的特定の結晶面が配向するので あると考えられる．ただし，優先配向面は，その結晶面によ り表面エネルギーが異なるため, 基板温度や動作ガス圧力に より変化する.めつき膜の場合, スピンスプレー法では比較 的優先配向面が現れやすいが, 超音波励起法など水溶液中で 膜が成長する他の方法では多くの結晶面からの回折ピークか 現れる傾向にある.これは膜成長が必ずしも基板表面だけで

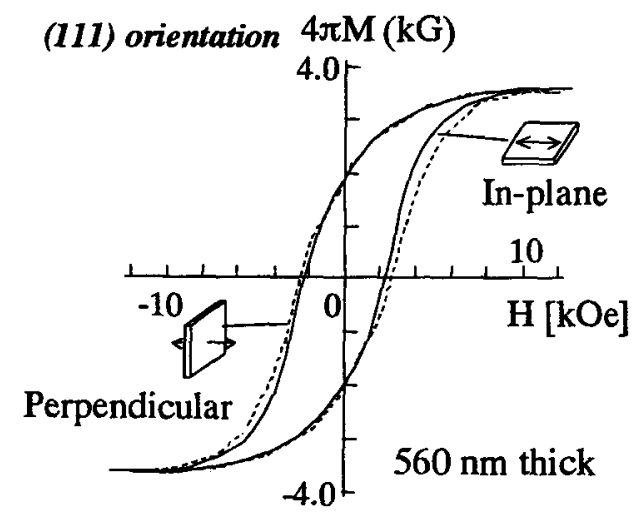

(a) Sputter-deposited $\mathrm{Co}-\mathrm{Zn}$ ferrite film Substrate temperature: $80^{\circ} \mathrm{C}$

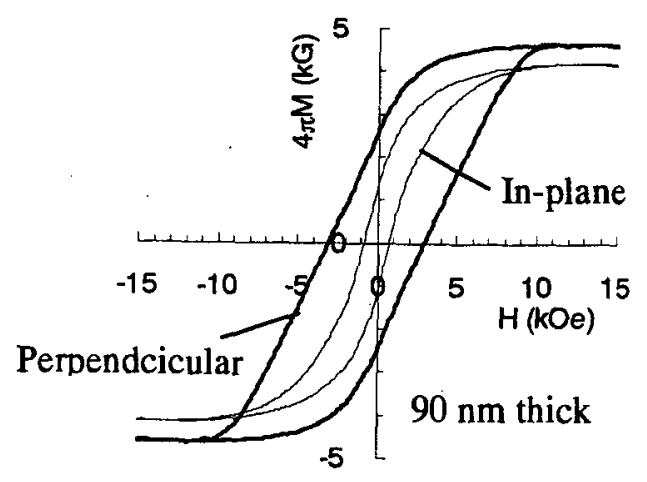

(b) Ferrite-plated Co-Ni ferrite film Substrate temperature: $90^{\circ} \mathrm{C}$

Fig.6 MH loops of (a) sputter-deposited Co- $\mathrm{Zn}$ ferrite film and (b) ferrite-plated Co-Ni ferrite film.
起こっているのではなく, 水中で生成したフェライト粒子も 膜中に取込まれているからであると考えられる。

磁気特性に関しては，条件を最適化することによって磁気 記録媒体としては十分な $3 \mathrm{kOe}$ 以上の保磁力が得られている. しかし, Fig.6に示すように, 垂直方向, 面内方向の $\mathrm{MH} ル-$ プを見ると，(a)のCo-Znフェライト・スパッタ膜では等方的 な, (b) のCo-Niフェライトめつき膜では垂直異方性のある膜 となっており，スピンの配向という点では大きく異なる.こ れを Fig.7に示したメスバウアー・スペクトルから解析する. 完全な面内配向膜では 6本のピークの面積比は左から $3: 4: 1$ $: 1: 4: 3$, 垂直配向膜では $3: 0: 1: 1: 0: 3$, 等方的な膜で $3: 2: 1$ :

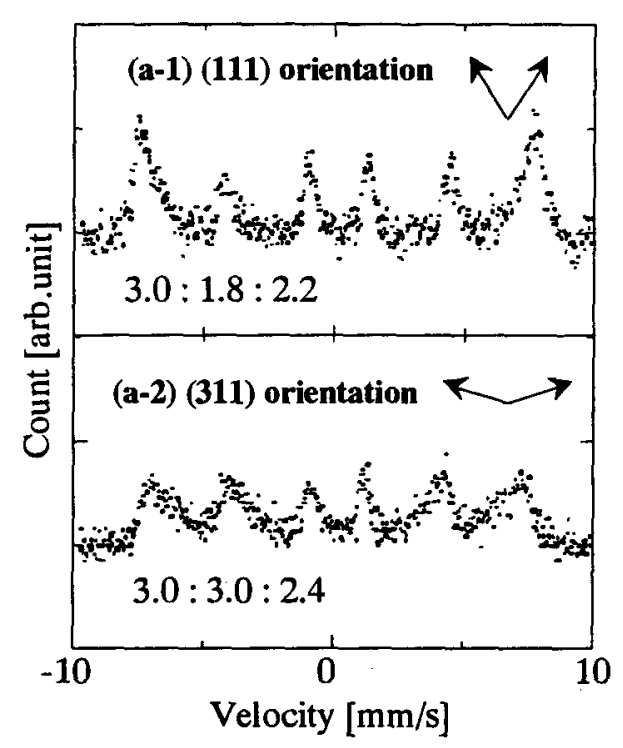

(a) Sputter-deposited $\mathrm{Co}-\mathrm{Zn}$ ferrite films

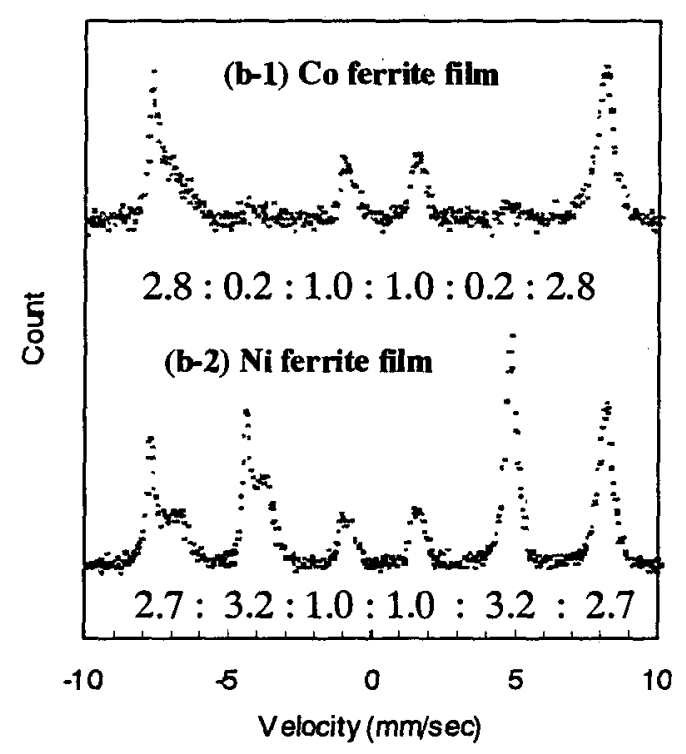

(b) Ferrite-plated Co ferrite and Ni ferrite films

Fig.7 Mössbauer spectra of (a-1), (a-2) sputter-deposited Co-Zn ferrite films, (b-1) ferrite-plated Co ferrite film, and (b-2) ferrite-plated Ni ferrite film. 
1:2:3となる. Co- $\mathrm{Zn}$ フェライト・スパッ夕膜では (a-1)の $80^{\circ} \mathrm{C}$ で作製した(111)配向膜でやや華直に近く, (a-2)の $400^{\circ} \mathrm{C} て ゙$ 作 製した(311)配向膜でやや面内に近い配向をしているが, (b-1) に示したCoフェライトめっき膜ほど特徵的ではなく,スパッ 夕膜はいずれも等方的な配向に近い。めつき膜では参考のた めに示した(b-2)の Niフェライト膜がほぼ面内配向であり, Co フェライト膜はピーク面積比が $2.8: 0.2: 1.0: 1.0: 0.2: 2.8$ とほ ほ垂直配向していることがわかる.この結果はFig.6に示した MHループの結果とよく一致する.Co-Znフェライトスパッ夕 膜では結晶磁気異方性から磁化容易軸が垂直方向から傾いて おり等方的な磁気配向を示すと考えることができる.Coフェ ライトめっき膜の場合は, 結晶磁気異方性から垂直異方性の 起源を説明することは困難であり, 応力に誘起された垂直磁 気異方性であると考えている。

飽和磁化 $4 \pi \mathrm{M}_{\mathrm{s}}$ に関しては, スパッ夕膜が $2.5 \sim 5 \mathrm{kG}$ である のに対し，めっき膜が 3.6〜 6kG と大きく，バルクの Co フェ ライトの值に近い。これはめっき膜が $4 \pi \mathrm{M}_{\mathrm{s}}$ の大きな $\mathrm{Fe}_{3} \mathrm{O}_{4}$ $(6 \mathrm{kG})$ を含んでいることにも起因するが, スパッ夕膜で $4 \pi \mathrm{M}_{\mathrm{s}}$ が低いものの中には非磁性相が含まれていることも考えられ

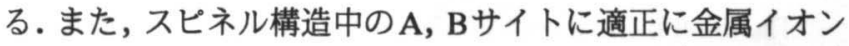
か配置されていないこともその一因として考えられる，その 他の研究例でもレーザーアブレーション法でNi-Znフェライト 膜の $4 \pi \mathrm{M}_{\mathrm{s}}$ がバルク值よりも小さいことが報告されており ${ }^{10)}$, ドライプロセスにおける典型例ともいえる。

このように, スパッ夕膜では表面形態, 結晶性に加え, 機 械的耐久性に優れるといった特長があるが, 今後さらに必要 度の増す垂直磁気記録媒体への応用という観点ではめっき膜 はすぐれた磁気特性を常温・常圧で実現できるメリットを有 している。

\section{BaM フェライト薄膜形成の低温化}

マグネトプラムバイト型 $\mathrm{Ba}(\mathrm{BaM})$ フェライトはスビネル型 フェライトと比較して複雑な結晶構造を有しているため, 厳 密なプロセス制御, 結晶化に $500^{\circ} \mathrm{C}$ を超える高温が必要とさ れることから，結晶粒子の微細化が困難であるなど記録媒体 への応用のためには解決すべき課題が多い。めつき法では, $\mathrm{Ba}$ フェライト薄膜の形成が試みられているものの ${ }^{11)}$, 結晶化 のために $800^{\circ} \mathrm{C}$ 以上での熱処理が必要で，かつ結晶性もス パッ夕膜に劣る。一方，スパッ夕法では， RF2 極方式などの 場合, 原子半径の大きな Baに十分な運動エネルギーを与える ことができない，あるいは膜がプラズマや高エネルギー粒子 の衝撃を受けるために, Ba原子か膜に取込まれにくく組成ず れを起こすなどの問題点があった．しかし，対向ターゲット 式スパッ夕法では, 本質的にプラズマフリーであり, Arより も大きな Xe ガスを混合したスパッ夕で，Ba原子にも十分な 運動エネルギーを与えることができたことにより，従来より 低い基板温度 $475^{\circ} \mathrm{C}$ で $4.7 \mathrm{kG}$ とバルク並みの $4 \pi \mathrm{M}_{s}$, $2 \mathrm{kOe}$ 以上 の保磁力を有し, 微細な結晶粒子からなる平坦な表面の薄膜 の形成に成功した ${ }^{12)}$.
6 ポリマー微粒子へのフェライト・コート

膜の微細構造や機械的強度については, 高いエネルギーを 原子やイオンに与えることのできるスパッ夕法に劣る点が多 いものの, 微粒子や複雑な形状の物体への製膜の場合にはウ エットプロセスであるフェライトめっき法でなければ行うこ とは困難である.フェライトをコートしたポリマー微小球(直 径 $0.25 \sim 4.5 \mu \mathrm{m}$ ) は免疫反応を利用した医療診断用磁性微粒子 としてすでに実用化されているが ${ }^{13}$, Fig.8(b)に示したように 連続膜にならず島状になっているものが存在する. そこで， $19.5 \mathrm{kHz}, 600 \mathrm{~W}$ の強力超音波を水溶液中に直接印加する超音 波励起法により，Fig.8(a)に示した連続膜のフェライト・コー ティングに成功した ${ }^{4}$. 強力超音波が誘導した膜構造の改善 は, イオンのマイグレーションを活性化したこと, 微粒子の 筧汼効果によるものと考えられる.さらに，酸化液を改良す ることによって，結晶粒子を微細化し，コーティング厚が $50 \mathrm{~nm}$ 程度でも連続膜を得ることができ，現行製品より水中で の分散性や磁気分離特性を向上させることができた ${ }^{14}$.

\section{7 ま と め}

フェライト薄膜堆積技術として, 対向ターゲット式スパッ 夕法とフェライトめっき法とを取上げ, 基板上あるいは基板 付近での原子やイオンのマイグレーションのエネルギーとい う観点から比較し, 膜の微細構造, 結晶性, 磁気特性の違い について述べた. 対向ターゲット式スパッ夕法ではプラズマ フリーの環境でかつ低動作ガス圧力での安定放電が可能であ るので，基板上で十分にマイグレーションするだけのエネル ギーを持った原子が最適なサイトに埋め込まれるように膜が 成長し,かつプラスマの衝擊により壊されることがないため, 表面平滑性, 結晶性, 機械的強度に優れた緻密な膜が得られ る.そのため, 磁気記録などマイクロ・ナノ磁気デバイスー の応用が期待される. 一方, フェライトめっき法は $100^{\circ} \mathrm{C}$ 以 下のプロセスであるため, 金属イオンがマイグレーションす るためのエネルギーが十分でなく, 膜構造や機械的強度の面 ではスパッ夕法に劣る. しかし, 耐熱性のない基板や特に微 粒子へのコーティングは, ウエットプロセスであるめっき法

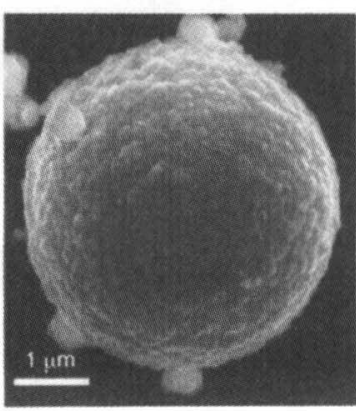

(a) with ultrasound enhancement

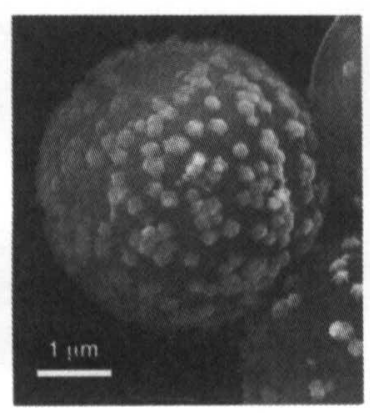

(b) without ultrasound enhancement
Fig.8 SEM photographs of ferrite-coated polymer particles prepared (a) with and (b) without ultrasound enhancement. 
でなければ困難な分野であり，プラスチックシートにコー ティングしたフレキシフルな磁気テバイスや磁性微粒子デバ イスの開発が期待されるとともに，製膜のために消費される エネルギーが少ないことが今後の環境対策に奇与すること大 であると考えられる.

\section{文献}

1) 直江正彦："磁性薄膜 I", 日本応用磁気学会誌，23(1999) 1752-1758.

2）阿部正紀: " フェライト膜の水溶液中作製とその応用 ", 日 本応用磁気学会誌, 22(1998)1225-1232.

3) M.Abe, Y.Tamaura, et al.: "Plating of ferrite films on 8 " disc at $70^{\circ} \mathrm{C}$ by spray-spin-coating method," IEEE Trans. Magn., 23 (1987)3432-3434.

4) M.Abe, Y.Kitamoto, et al.: "Ultrasound Enhanced Ferrite Plating: Bringing Breakthrough in Ferrite Coating Synthesized from Aqueous Solution", IEEE Trans. Magn., 33(1997)3649-3651

5) N.Matsushita, et al.: "Preparation of Co Ferrite Thin Films with Large Perpendicular and In-Plane Coercivities by Facing Targets Sputtering", IEEE Trans. Magn., 28(1992)3108-3110.

6) N.Matsushita, et al.: "Preparation of Co-Zn Ferrite Films at Low Substrate Temperature by Plasma-free DC Sputtering *.", J. Appl. Phys., 75(1994)5975-5977.
7) N.Matsushita, et al.: "Control of Crystallographic and Magnetic Characteristics in Co-Zn Ferrite Sputtered Films", J. Magn. Magn. Mater., 140-144(1995)2085-2086.

8) Y.Kitamoto, et al.: "Co Ferrite Films with Excellent Perpendicular Magnetic Anisotropy and High Coercivity Deposited at Low Temperature", J. Appl. Phys., 85(1999)4708-4710.

9) 張福春, 北本仁孝, 阿部正紀: "Coフェライト薄膜における $\mathrm{Ni}$ の添加効果 ", 粉体粉末治金協会 平成 11 年度春季大会, (1999)142.

10) 三上實祐他: "レーザーアブレーション法による $\mathrm{NiZnフェ}$ ライト薄膜", 日本応用磁気学会誌, 20(1990)329-332.

11) 宮崎暁, 北本仁孝, 阿部正紀 : " 高 $\mathrm{pH}$ 領域でのめっきによ る Ba フェライト薄膜 ", 粉体粉末治金協会 平成 11 年度秋 季大会, (1999)228.

12) K.Noma, et al.: "Ba Ferrite Films with Large Saturation Magnetization and High Coercivity Prepared by Low Temperature Sputter Deposition", J. Appl. Phys., 79(1996)5970-5972.

13) S.Nagahata, et al.: "Ferrite-Coated Polymer Microspheres Prepared by Ferrite Plating for Immunoassay", Proceedings of The Sixth International Conference on Ferrites, (1992)279-282.

14) M.Ojima, F.Shirasaki, Y.Kitamoto, et al.: "Ultrasound Enhanced Ferrite Plating of Polymer Microspheres for Magnetic Cellular Segregation", IEEE Trans. Magn., 35(1999)4118-4120. 